\title{
Short Communication: Application of artificial reefs for fisheries enhancement in Probolinggo, Indonesia
}

\author{
WAHYU ISRONI, SYIFANIA H. SAMARA, MUHAMMAD B. SANTANUMURTI \\ Department of Fish Health Management and Aquaculture, Fisheries and Marine Faculty, Universitas Airlangga, Campus C, Jl. Dharmahusada Permai \\ 330, Mulyorejo, Surabaya 60115, East Java, Indonesia. Tel. +62-315911541, •email: m.browijoyo.s@fpk.unair.ac.id
}

Manuscript received: 27 May 2019. Revision accepted: 23 July 2019

\begin{abstract}
Isroni W, Samara SH, Santanumurti MB. 2019. Short Communication: Application of artificial reefs for fisheries enhancement in Probolinggo, Indonesia. Biodiversitas 20: 2273-2278. Overfishing is one of the biggest challenges in the fisheries sector in Probolinggo, Indonesia. The fish apartment (artificial reefs) was one of the solutions to increase the fish resource since it serves as the habitat for fish to live, spawn, and search for food. In this study, the fish apartment was installed in Probolinggo (Karang Katon and Dringu Beach) from 2017 to 2018. This study showed that five fish species (Caesio cuning, Acanthurus achilles, Acanthurus albipectoralis, Sphyraena jello, and Apagon novemfasciatus) were found in Karang Katon while four species (Chaetodon octofasciatus, Chromobotia macracanthus, Nemipterus japonicas, and Lates calcarifer) lived in Dringu Beach. From a total of 333 fishes, A. achilles was the species with the highest composition level of 51.65\% (172) in Karang Katon station. In Dringu Beach station, C. octofasciatus had the highest fish species composition level of 46\% (183) from a total of 402 fishes. The diversity index and dominance index in Karang Katon station were low at-1.280 and 0.343, respectively. The diversity index and dominance index in Dringu Beach station were also low at -1.115 and 0.3503 . A. achilles had the highest density of $34.4 \mathrm{ind} / \mathrm{m}^{3}$ in Karang Katon station while C. octofasciatus had the highest species density of $36.6 \mathrm{ind} / \mathrm{m}^{3}$ in Dringu Beach Station. From this study, it could be concluded that artificial reefs application enhanced the fisheries in Probolinggo, Indonesia, and help its sustainability.
\end{abstract}

Keywords: Density, diversity index, dominance index, fish apartment, Probolinggo

\section{INTRODUCTION}

Indonesia is known as an archipelagic country that consists of more than 17,000 small islands with a coastline of $81,000 \mathrm{~km}$ (Nikijuluw 2017). Consisting of mainly coastal areas, Indonesia has high marine and coastal potential such as marine fish. However, Indonesia faces overfishing problems. Overfishing is a serious problem because it reduces fishery production, causes conflict between fisheries actors, reduces community income, and damage the coastal communities (Muawanah et al. 2012).

Overfishing also occurs in Probolinggo, Indonesia. Probolinggo's capture fisheries experienced a production decline in 2017 compared to 2016, where the 2017 production was recorded at $19,239.80$ tons while it was 19,740.78 tons in 2016 (Badan Pusat Statistik Probolinggo 2018). The decreasing fish resource is an impact of the increasingly intensive fishing activities. The use of nonenvironmentally friendly fishing gear, violation of fishing lanes, and decreased carrying capacity due to degradation of essential fish habitats are also the cause for the decreasing fish resource. The habitat is critical in sustaining fish resource reproduction because it functions as a spawning ground, nursery ground, and feeding areas (Bambang et al. 2011). Given this situation, one quick alternative to increase fish catches is by installing a fish apartment as artificial reefs.
The fish apartment is one of the tools intended to maintain the sustainability of fish resource utilization. It is a hollow structure composed of solid objects placed in the water which serves as a gathering place for organisms, especially fish. The installed fish apartment can increase fishing efficiency and natural productivity by providing new habitat for attaching organisms that contribute to the food chain as well as the target species. It can also protect small or juvenile organisms as a nursery ground and protect from waves, strong currents, and predators. Furthermore, it also increases the complexity of essential habitats, so it functions similar to the components of a physical reef environment (Pickering et al. 1998; Jensen 2002; McLean et al. 2014; Rendle and Rodwell 2014; Wu et al. 2015).

Based on its function, the fish apartments have been proven to be an artificial habitat that efficiently attracts fish and increase catches of the fishing communities (Kuhl 1992; Bombace et al. 1994; Pickering and Whitmarsh 1997; Brickhill et al. 2005; Creque et al. 2006; Dumont et al. 2011; Kelch 2012). In East Java, many studies showed that fish apartment had been used to enhance the fisheries sustainability (Yanuar and Aunurohim 2015; Fuad et al. 2016; Kamaali et al. 2017; Sabrini and Nugraha 2019).

Therefore, it is highly necessary to monitor the condition of existing fish apartments. The monitoring aims to assess the practical suitability of these devices, whether the fish apartments has an impact on the restoration of the fish resource ecosystem in the region. Eventually, this will 
lead to fish diversity in the area around the fish apartments in Probolinggo.

\section{MATERIALS AND METHODS}

\section{Description of the study sites}

This study was a survey study conducted in Karang Katon $\left(113^{\circ} 12^{\prime} 45.70^{\prime \prime} \mathrm{E}\right.$ and $7^{\circ} 41^{\prime} 23$ "S) and Dringu Beach $\left(113^{0} 15^{\prime} 57.89^{\prime \prime}\right.$ E - $7^{0} 44^{\prime} 33.95^{\prime \prime S}$ and $113^{\circ} 16^{\prime} 21.65^{\prime \prime}$ E-7045'7.96"S), Probolinggo District, East Java Province, Indonesia (Figure 1). The fish house location was determined as described in the previous study (Wibowo et al. 2016). The survey was conducted at a depth of 15 meters. The method used in this research was an Underwater Visual Census (UVC) survey (Puspitasari et al. 2013).

\section{Fish apartment}

The primary material used to build the fish apartment frames was Polypropylene (pp) type plastic. The polypropylene material was chosen because it was readily available and can be produced in the desired amount, relatively safe (non-toxic), insoluble in water, durable, and safe for humans and the environment (Bambang et al. 2011). The fish apartments were installed for one year from October $22^{\text {nd }}, 2017$ to October $22^{\text {nd }}, 2018$. The survey was conducted from October $23^{\text {rd }}, 2018$ to November $1^{\text {st }}, 2018$.

The fish apartment frames consisted of a vertical partition $(35 \mathrm{~cm} \times 35 \mathrm{~cm})$ and horizontal partition measuring $35 \mathrm{~cm}$ x $35 \mathrm{~cm}$. After the horizontal and vertical partition was formed, then the partition was arranged into a sub-module consisting of 4-5 partitions with a height of
$175 \mathrm{~cm}$. Four sub-modules were assembled and attached to weights $3 \mathrm{~kg}$ with of sized $1100 \mathrm{~mm}$ x $125 \mathrm{~mm}$ x $125 \mathrm{~mm}$ made of size six iron and cast concrete and $6 \mathrm{~mm}$ PE rope for hooks. One fish apartment module consisted of 4 submodules which were put together with around 123 sets of the entire partition. The fish apartment design could be seen in Figure 2.

\section{Data collection}

The underwater visual census (UVC) method developed by Cappenberg (2009) was used to observe the condition of existing settlements for fish and aquatic organisms. The observation was conducted through diving and documented using Nikon Coolpix W300 (Japan) underwater camera. Recording of fish species and individuals were conducted by identifying the commodities that come across the transects.

The data collection used belt transects of slap rope type method placed in two locations (Karang Katon and Dringu) with 2 transects per site. The enclosed area was the fish house area. Each site was observed using visual techniques. The observed area per transect was $128 \mathrm{~m}$ x $500 \mathrm{~m}$ x $15 \mathrm{~m}$.

Observation of the fish population was conducted through direct observation in water, focusing on areas per embedded module. Underwater observations were recorded and assisted by cameras for taking photos or videos.

The data obtained as either photos or videos were used to simplify the calculation and identify the fish species (Allen 1999) found in the fish apartment, which were then grouped by family. Data acquisition was processed to determine the value of species composition, density, fish diversity index, and species dominance index.
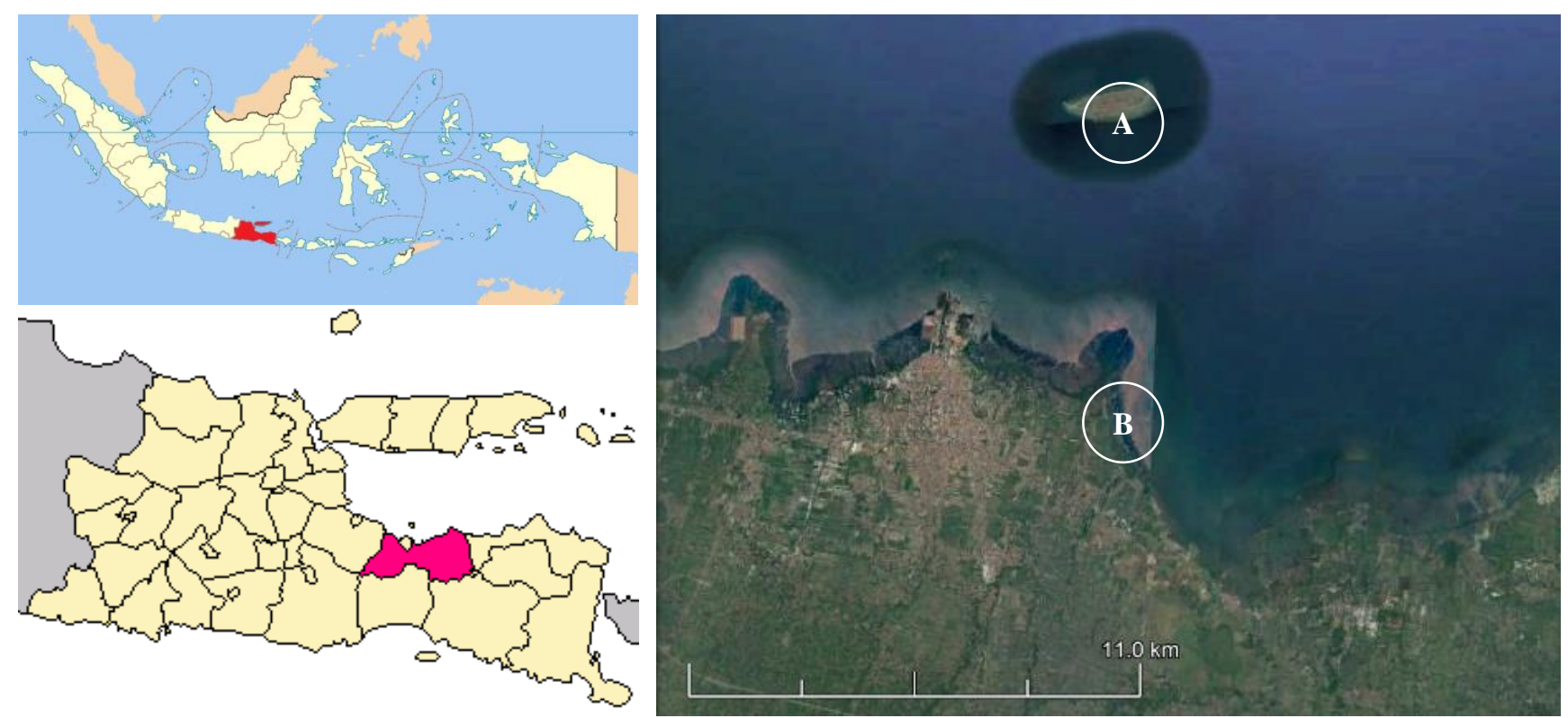

Figure 1. Sample point location of fish apartment in Probolinggo District, East Java Province, Indonesia. A. Karang Katon, B. Dringu Beach 


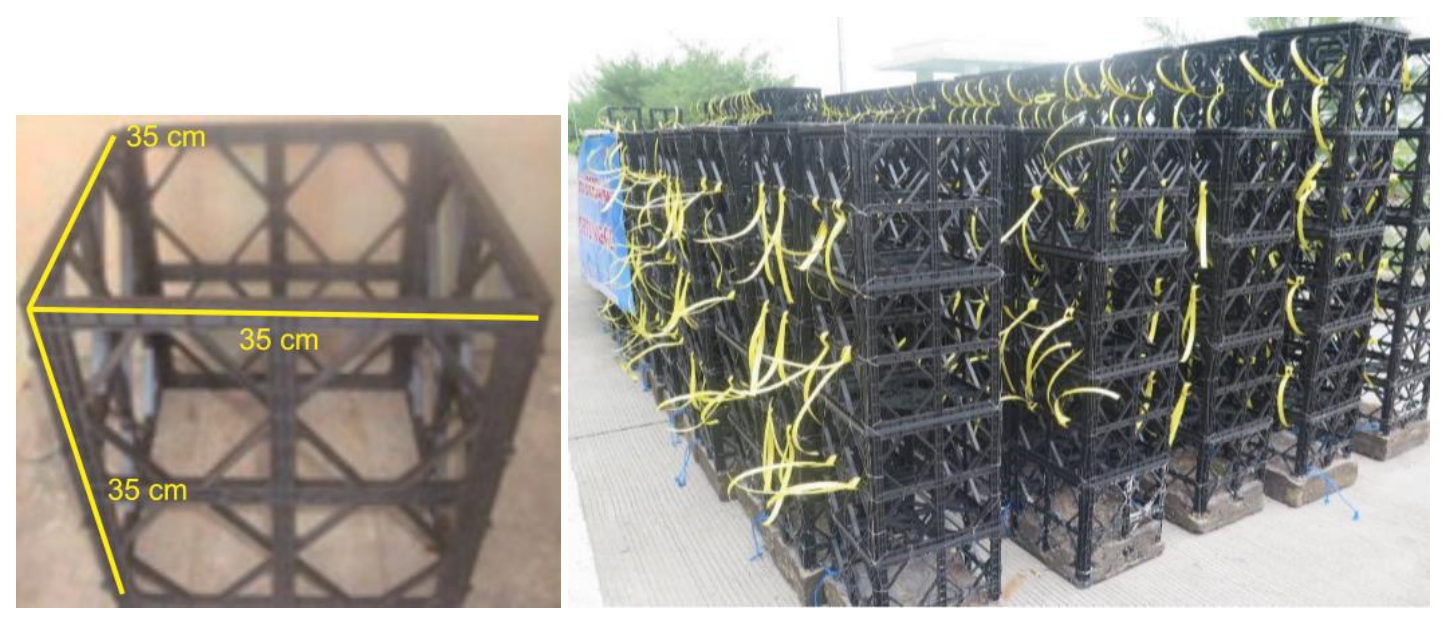

Figure 2. Fish apartment partition (left), fish apartment design (right)

\section{Data analysis}

The fish apartment success was measured by the parameters of fish species composition, density, diversity index, and dominance index. The analysis details were as follows:

Fish species composition. Fish species composition was the proportion of total fish for each species (Rappe 2010).

Density. Density was the number of individuals and the number of species found in the area of observation. The density of reef fish could be calculated using the following formula (Pope et al. 2010):

$$
X=\frac{\sum X i}{n}
$$

Where: X: Fish density, Xi: Number of fish at location, $\mathrm{n}$ : Area of observation transect $\left(\mathrm{m}^{3}\right)$

Diversity index. Diversity index was used to obtain a quantitative description of the organism's population (Odum 1971). This calculation could facilitate the analysis of information on the number of individuals in each reef fish community Diversity could be calculated using the following formula:

$$
H^{\prime}=\sum_{l=1}^{s}(P i)(\ln p i)
$$

Where: H': Shannon Wiener Diversity index, Pi: Proportion of comparison of the number of individuals $i$ (ni) $\mathrm{i}$ with the number of individuals $(\mathrm{N}), \mathrm{i}: 1,2,3$, $\mathrm{S}$ : Number of species of fish

Dominance index. A small index of uniformity and diversity was used to indicate a high dominance of a species against other species. The dominance index formula was as follows (Odum 1971):

$$
C=\sum_{i=1}^{s}\left(p i^{2}\right)
$$

Where: C: Shannon Wiener dominance index, pi: Proportion of species number $\mathrm{i}(\mathrm{n})$, to total number of reef fish $(\mathrm{N})$ : n / N, s: Number of reef fish species, Index value based on $0-1$ with category as follows: (i) $0<\mathrm{C}<0.5=$ Low dominance, (ii) $0.5<\mathrm{C}=0.75=$ Moderate dominance, (iii) $0.75<\mathrm{C}<1.0=$ High dominance

\section{RESULTS AND DISCUSSION}

\section{Fish species}

During the study, data from the underwater visual census (UVC) survey found that there were 5 fish species in Karang Katon, namely yellowtail fish (Caesio cuning), Achilles tang (Acanthurus achilles), whitefin surgeonfish (Acanthurus albipectoralis), pick handle barracuda (Sphyraena jello), and seven-striped cardinalfish (Apagon novemfasciatus). In Dringu Beach, four fish species were found, namely the butterflyfish (Chaetodon octofasciatus), clownfish (Chromobotia macracanthus), threadfin bream (Nemipterus japonicus), and white snapper (Lates calcarifer). The fish observation results obtained in this study can be seen in Table 1.

\section{Karang Katon}

Acanthurus achilles fish was the fish species with the highest composition level of $51.65 \%$ while the lowest was A. novemfasciatus at $3 \%$. The UVC results showed that $A$. achilles had the abundance or density of $34.4 \mathrm{ind} / \mathrm{m}^{3}$. On the other side, the Apogon novemfasciatus had the lowest abundance equal to $2 \mathrm{ind} / \mathrm{m}^{3}$. The diversity index analysis showed that the fish in Karang Katon station had low diversity of -1.280 . The dominance index analysis showed that fish in the fish apartments in KarangKaton station had a low dominance value of 0.343 . 
Table 1. Fish observation results in Karang Katon and Dringu Beach station fish apartments, Probolinggo District, East Java Province, Indonesia

\begin{tabular}{llccccc}
\hline Location & Fish Species & Number of fish & Density & Composition (\%) & H' & Dominance \\
\hline Karang Katon & Caesio cuning & 72 & 14.4 & 21.62 & -0.331 & 0.047 \\
& Acanthurus achilles & 172 & 34.4 & 51.65 & -0.341 & 0.267 \\
& Acanthurus albipectoralis & 46 & 9.2 & 13.81 & -0.273 & 0.019 \\
& Sphyraena jello & 33 & 6.6 & 9.91 & -0.229 & 0.010 \\
& Apogon novemfasciatus & 10 & 2 & 3.00 & -0.105 & 0.001 \\
& Total & 333 & 66.6 & 100 & -1.280 & 0.343 \\
& & & & & -0.358 & 0.2072 \\
Dringu Beach & Chaetodon octofasciatus & 183 & 36.60 & 46 & -0.343 & 0.0582 \\
& Chromobotia macracanthus & 97 & 19.40 & 24 & -0.359 & 0.0847 \\
& Nemipterus japonicus & 117 & 23.40 & 29 & -0.055 & 0.0002 \\
& Lates calcarifer & 5 & 1.00 & 1 & -1.115 & 0.3503 \\
\hline
\end{tabular}

\section{Dringu}

Chaetodon octofasciatus had the highest fish species composition level of $46 \%$ while the lowest was Lates calcarifer at $1 \%$. Based on the UVC survey results, $C$. octofasciatus had the highest species abundance or density of $36.6 \mathrm{ind} / \mathrm{m}^{3}$. Fish with the lowest abundance was Lates calcarifer at $1 \mathrm{ind} / \mathrm{m}^{3}$. The diversity index analysis showed that fish in Dringu Beach station had a low diversity of 1.115. The dominance index analysis showed that fish in Dringu Beach station had a low dominance value of 0.3503 .

\section{Discussion}

The presence of fish gathered in the fish apartments showed that this artificial reef could help fisheries sustainability in Probolinggo. Previously before the application of this device, many studies stated that the condition of coral reefs in Probolinggo was damaged up to 71.62\%. (Jaelani et al. 2015; Puspitasari et al. 2013; Wiyanto 2016). The damage process of coral reefs in Probolinggo occurred due to the bleaching process, overwhelming fishing, destructive fishing methods, sedimentation and land pollution (Jaelani and Afifi 2016; Wiyanto 2016). Damage to coral reefs makes it challenging to find fish in the coastal waters of Probolinggo because of the inadequate stock (Permana 2017; Rachman et al. 2014). The decreasing fish was 500.98 lower than in 2016 (Badan Pusat Statistik Probolinggo 2018). In 2017, the rate of exploitation reached 0.71 per year with a utilization rate of $140 \%$, and biomass in Probolinggo was low (Meyanti 2017). Even fishers from Probilinggo were looking for fish from the Aru Sea or the Arafura Sea and the Timor Sea to be traded in Mayangan, Probolinggo (Suprapto 2017).

The fish apartments would affect upwelling and carry nutrients such as natural coral reefs ( $\mathrm{Yu}$ et al. 2015). It could increase the nutrient content in the upper-lower of seawater and sediment that it had a role as fish foraging (Wang et al. 2018). It would attract the fishes to go to the fish apartment because of the abundant food such as phytoplankton and zooplankton growth. Over time, nutrients and organic matter concentrate in the apartment (Leitão 2013). The emerging phytoplankton and zooplankton invited plankton-eating fish to come to the apartment (Champion et al. 2015; Truong et al. 2017). Fish apartments were also a place for macroalgae to attach itself and gradually transform the fish apartments to be like real corals (Wu et al. 2015). Macroalgae also attracted herbivorous fish to come to the fish apartment.

In Karang Katon station, A. achilles had the highest species density. The high density might be due to the $A$. achilles nature which habitat was in the reef (Montanari 2016). In Dringu Beach, C. octofasciatus was the highest species density since its natural habitat was the coral reef (Nowicki 2018). The appearance of these two species (A. achilles and $C$. octofasciatus) showed that fish apartment helped fisheries sustainability. Chaetodontid fish such as $C$. octofasciatus and A. achilles were fish indicators species that indicated that these coral reef ecosystems are high nutritious (Hobson 1972; Yanuar and Aunurohim 2015). In East Java, C. octofasciatus was previously reported to be found only in Pasir Putih (Situbondo), Teluk Prigi (Trenggalek), and Pulau Kambing (Madura) (Sumadhiharga 2006; Wibowo and Adrim 2014; Yanuar and Aunurohim 2015).

While A. achilles was reported in Bangsring, Banyuwangi (Asadi and Andrimida 2017). On the other side, the Apogon novemfasciatus was the lowest density in Karang Katon since its habitat was a muddy bottom (Goren et al. 2009) while in Dringu, white snapper (Lates calcarifer) because its habitat that was not specific to coral, just finding small fish to be eaten (Campbell et al. 2017).

Acanthurus achilles main diet consisted of algae that grow in fish apartments while the $C$. octofasciatus ate plankton (Jones 1968; Sazima and Sazima 2001). Due to the abundant plankton and algae growing in the fish apartment, the two fish species dominated the location. Other fish, C. cuning, was a plankton feeder that consumes both phytoplankton and zooplankton (Zamani et al. 2011). A. albipectoralis fish was a planktivorous predator (Goren et al. 2009).

The existence of these fish also attracted animals at a higher level of the food pyramid to go to this area, carnivores, and omnivorous animals to come to fish apartments (Champion et al. 2015). The presence of S. jello 
showed in Karang Katon and Lates calcarifer fish appeared in Dringu proved that previous study. The interesting thing about this study was the discovery of barracuda ( $S$. jello), which appeared in East Java had not been frequently reported. Previous research had stated that $S$. jello was found in Muncar (Banyuwangi) and Watukarung (Pacitan) (Sanjaya 2018; Wijaksono and Mudzakir 2014). Barracuda could be found in this study because barracuda used coral reefs as a place to find food and shelter (Bharathi and Ponni 2018; Hosseini et al. 2009). The presence of this fish would create a dynamic food chain and ecosystem, so fish apartments could be a habitat for fish to feed, spawn, and grow (McLean et al. 2015). Previous research reported that fish apartment had been applied in various places in East Java (Kamaali et al. 2017; Fuad et al. 2016; Yanuar and Aunurohim 2015; Sabrini and Nugraha 2019).

This study only provided a single snapshot in time, and ongoing monitoring was necessary to be conducted in the future since it needed time to develop as coral habitat. Previous research showed that artificial reef requires five years to get optimum results (Le Diréach 2015).

To conclude, this study had successfully documented fish apartment installation in KarangKaton and Dringu Beach station for one year. It could be concluded that the application of fish apartment could enhance the fisheries sustainability in Probolinggo.

\section{ACKNOWLEDGMENTS}

We are grateful for the close collaboration with the Office of Marine and Fisheries, East Java Province, Indonesia in completing this study.

\section{REFERENCES}

Allen G. 1999. Marine Fishes of South-East Asia: A field guide for anglers and divers. Tuttle Publishing, Vermont.

Asadi MA, Andrimida A. 2017. Economic valuation of coral reefs ecosystem of Bangsring, Banyuwangi, Indonesia. ECSOFiM (Economic and Social of Fisheries and Marine) 4: 144-152.

Bambang N, Widodo, Suryadi A, Wassahua Z. 2011. Apartemen Ikan (Fish Apartment) Sebagai Pilar Pelestarian Sumberdaya Ikan. Bala Besar Pengembangan Penangkapan Ikan, Direktorat Jendral Perikanan Tangkap, Kementrian Kelautan dan Perikanan, Jakarta, Indonesia. [Indonesian]

Badan Pusat Statistik Probolinggo. 2018. Kabupaten Probolinggo Dalam Angka Tahun 2018. Badan Pusat Statistik, Probolinggo, Indonesia. [Indonesian]

Bharathi M, Ponni AC. 2018. Food and feeding analysis of marine fish Sphyraena jello. Asian J Innov Res 3: 50-53.

Bombace G, Fabi G, Fiorentini L, Speranza S. 1994. Analysis of the efficacy of artificial reefs located in five different areas of the adriatic sea. Bull Mar Sci 55: 559-580.

Brickhill MJ, Lee SY, Connolly RM. 2005. Fishes associated with artificial reefs: attributing changes to attract ion or production using novel approaches. J Fish Biol 67: 53-71.

Campbell AB, Robins J, O'Neill MF. 2017. Assessment of the barramundi (Lates calcarifer) fishery in the Southern Gulf of Carpentaria, Queensland, Australia. [Project Report]. State of Queensland, Department of Agriculture and Fisheries, Brisbane, Queensland, Australia.

Cappenberg HD. 2009. Monitoring Kesehatan Terumbu Karang Kabupaten Bintan (Pulau-pulau Tambelan). Coremap - LIPI, Jakarta, Indonesia. [Indonesian]
Champion C, Suthers IM, Smith JA. 2015. Zooplanktivory is a key process for fish production on a coastal artificial reef. Mar Ecol Prog Ser 541:1-14.

Creque SM, Raffenberg MJ, Brofka WA, Dettmers JM. 2006. If you build it, will they come? fish and angler use at a freshwater artificial reef. $\mathrm{N}$ Am J Fish Manag 26:702-713.

Dumont P, Amours JD, Thibodeau S, Dubuc N, Verdon R, Garceau S, Bilodeau P, Mailhot Y, Fortin R. 2011. Effects of the development of a newly created spawning ground in The Des Prairies River (Quebec, Canada) on the reproductive success of lake sturgeon (Acipenser fulvescens). J Appl Ichthyol 27: 394-404.

Fuad MAZ, Sambah AB, Isdianto A, Andira A. 2016. Pemetaan batimetri sebagai informasi dasar untuk penempatan fish apartment di perairan Bangsring, Kabupaten Banyuwangi, Jawa Timur. DEPIK Jurnal IlmuIlmu Perairan, Pesisir dan Perikanan 5: 143-150. [Indonesian]

Goren M, Galil BS, Diamant A, Gayer K., Stern N. 2009. First record of the Indo-Pacific cardinal fish Apogon fasciatus (White, 1790) in the Mediterranean Sea. Aquat Invasions 4: 409-411.

Hobson ES. 1972. Activity of hawaiian reef fishes during the evening and morning transitions between daylight and darkness. Fish Bull 70: 715-740.

Hosseini SA, Jamili S, Valinassab T, Vosoghi G, Fatemi SMR. 2009. Feeding and spawning of Sphyraena jello in the North-West of Persian Gulf. J Fish Aquat Sci 4: 57-62.

Jaelani LM, Afifi Z. 2016. Study of Coral Bleaching Mapping using High Resolution Images (A Case Study: The Water Area of PLTU Paiton Probolinggo). Geoid 11(2): 144-150.

Jaelani ML, Lalli N, Marini Y. 2015. Pengaruh Algoritma lyzenga dalam pemetaan terumbu karang menggunakan worldview-2, studi kasus: Perairan PLTU Paiton Probolinggo. J Penginderaan Jauh 12: 123. [Indonesian]

Jensen A. 2002. Artificial reefs of Europe: perspective and future. ICES J Mar Sci 59: S3-S13.

Jones RS. 1968. Ecological relationships in Hawaiian and Johnston Island Acanthuridae (surgeon fishes). Micronesica 4: 309-361.

Kamaali MW, Baskoro MS, Wisudo SH. 2017. Pengkayaan sumberdaya ikan dengan fish apartment di Perairan Bangsring, Banyuwangi. Jurnal Teknologi Perikanan dan Kelautan 7: 11-20. [Indonesian]

Kelch DO. 2012. Lake Erie's Artificial Reef Program: Build It And They Will Come. Ohio Sea Grant, Fact Sheet Series FS-072, Ohio, US.

Kuhl D. 1992. 14 Years of artificial grain feeding in the Rhine Downstream of the Barrage Iffezheim. In: Larsen P, Eisenhauer N (Eds.), Proceedings of the 5th International Symposium on River Sedimentation, University of Karlsruhe, Karlsruhe, Germany, 610April 1992.

Le Diréach L, Astruch P, Bonhomme D, Bonhomme P, Fourt M, Rouanet E, Adrien G, Ruitton S. 2015. Comparative assessment of the deployment of 6 artificial reef types in Marseille Prado Bay (France) from a five-year seasonal survey of the fish fauna; Proceedings of the RECIFS Conference on Artificial Reefs: from Materials to Ecosystems, Caen, France, 27-29 January 2015.

Leitão F. 2013. Artificial reefs: from ecological processes to fishing enhancement tools. Brazilian J Oceanogr 61: 77-81.

McLean M, Roseman EF, Pritt JJ, Kennedy G, Bruce A, Manny BA. 2014. Review: Artificial reefs and reef restorationin the Laurentian Great Lakes. J Great Lakes Res 41: 1-8.

Meyanti H. 2017. Dinamika Populasi Ikan Tembang (Sardinella Fimbriata Valenciennes, 1847) Di Probolinggo, Jawa Timur. [Dissertation]. Brawijaya University, Malang. [Indonesian]

Montanari SR, Hobbs JPA, Pratchett MS, Van Herwerden L. 2016. The importance of ecological and behavioural data in studies of hybridisation among marine fishes. Rev Fish Biol and Fisher 26: 181198.

Muawanah U, Pomeroy RS, Marlessy C. 2012. Revisiting fish wars: conflict and collaboration over fisheries in Indonesia. Coast Manage 40: 279-288.

Nikijuluw VP. 2017. Coastal resources conservation in Indonesia: Issues, policies, and future directions. Sumatra J Disaster, Geogr Geogr Educ 1: 15-23.

Nowicki JP, O'Connell LA, Cowman PF, Walker SP, Coker DJ, Pratchett MS. 2018. Variation in social systems within Chaetodon butterflyfishes, with special reference to pair bonding. PLoS ONE 13(4): e0194465. DOI: 10.1371/journal.pone.0194465

Odum EP. 1971. Dasar-dasar Ekologi. Gadjah Mada University Press, Yogyakarta, Indonesia. [Indonesian] 
Permana RBA. 2017. Analisis Keberlanjutan Pengelolaan Sumberdaya Ikan Demersal Di Perairan Pantai Utara Pelabuhan Perikanan Mayangan Kota Probolinggo Jawa Timur. [Dissertation]. Brawijaya University, Malang. [Indonesian]

Pickering H, Marsh DW, Jensen A. 1998. Artificial reefs as a tool to aid rehabilitation of coastal ecosystems: investigating the potential. Mar PollutBull 37: 505-514.

Pickering H, Whitmarsh D. 1997. Artificial reefs and fisheries exploitation: a review of the "attraction versus production"debate, the influence of design and its significance for policy. Fisher Res 31: 3959.

Pope KL, Lochmann SE, Young MK. 2010. Methods for assessing fish populations. In: Hubert, Wayne A, Quist, Michael C (eds). Inland Fisheries Management in North America, 3rd edition. MD: American Fisheries Society, Bethesda.

Puspitasari L, Samino S, Retnaningdyah C. 2013. Alteration of coral reef community structure caused by athropogenic activity in coastal area of Giliketapang Island, Probolinggo, East Java, Indonesia. JTrop Life Sci 3: 23-27.

Rachman S, Purwanti P, Primyastanto M. 2013. Analisis faktor produksi dan kelayakan usaha alat tangkap payang di Gili Ketapang Kabupaten Probolinggo Jawa Timur. ECSOFiM (Economic and Social of Fisheries and Marine) 1: 69-81. [Indonesian]

Rappe RA. 2010. Fish community structure in different seagrass beds of Barrang Lompo Island. Jurnal Ilmu dan Teknologi Kelautan Tropis 2: 62-73.

Rendle EJ, Rodwell LD. 2014. Artificial surf reefs: a preliminary assessment of the potential to enhance a coastal economy. Mar Policy 45: $349-358$

Sabrini R, Nugraha Y. 2019. Teknik pembuatan dan pemasangan terumbu buatan sebagai habitat lobster di Teluk Prigi Kabupaten Trenggalek Jawa Timur. Buletin Teknik Litkayasa Sumber Daya dan Penangkapan 16: 37-43. [Indonesian]

Sanjaya R. 2018. Analisis Kelayakan Usaha Dan Strategi Pengembangan Usaha Perikanan Bagan Apung Di Daerah Perairan Muncar Kabupaten Banyuwangi Jawa Timur. [Dissertation]. Brawijaya University, Malang. [Indonesian]
Sazima C, Sazima I. 2001. Plankton-feeding aggregation and occasional cleaning by adult butterflyfish, Chaetodon striatus (Chaetodontidae), in southwestern Atlantic. Cybium 25: 145-151.

Sumadhiharga OK. 2006. Study on coral reef fishes diversity of Kambing Island, Madura Strait, East Java, Indonesia, AGRIS, Japan.

Suprapto S. 2017. Keragaan penangkapan ikan demersal di kawasan timur indonesia yang berbasis di Probolinggo. BAWAL Widya Riset Perikanan Tangkap 2: 123-131. [Indonesian]

Truong L, Suthers IM, Cruz DO, Smith JA. 2017. Plankton supports the majority of fish biomass on temperate rocky reefs. Mar Biol 164: 73

Wang Y, Sun J, Fang E, Guo B, Dai Y, Gao Y., Wang H, Zhang X, Xu X, Yu Y, Liu K. 2018. Impact of artificial reefs on sediment bacterial structure and function in Bohai Bay. Can J Microbiol 65: 191-200.

Wibowo K, Adrim M. 2014. Komunitas ikan-ikan karang Teluk Prigi, Trenggalek, Jawa Timur. Zoo Indonesia 22: 29-38. [Indonesian]

Wibowo TW, Chasanah N, Maksum K. 2016. Penentuan Lokasi Rumah Ikan. Balai Besar Penangkapan Ikan Direktorat Jenderal Perikanan Tangkap, Kementerian Kelautan dan Perikanan, Semarang, Indonesia. [Indonesian]

Wijaksono BPN, Mudzakir AK. 2014. Analisis aspek teknis dan finansial alat tangkap tonda di TPI Watukarung Kabupaten Pacitan. Journal of Fisheries Resources Utilization Management and Technology 3: 183189. [Indonesian]

Wiyanto DB. 2016. Coral reef coverage percentage on Binor PaitonProbolinggo Seashore. J Mar Aquatic Sci 2: 6-10.

Wu Z, Zhang X, Lozano-Montes MH, Loneragan NR. 2015. Trophic flows, kelp culture and fisheries in the marine ecosystem of an artificial reef zone in the yellow sea. Estuar Coast Shelf Sci 182: 86-97.

Yanuar A, Aunurohim A. 2015. Komunitas ikan karang pada tiga model terumbu buatan (artificial reef) di Perairan Pasir Putih Situbondo, Jawa Timur. Jurnal Sains dan Seni ITS 4: E19-E24. [Indonesian]

Yu J, Chen P, Tang D, Qin C. 2015. Ecological effects of artificial reefs in Daya Bay of China observed from satellite and in situ measurements. Advances in Space Research 55: 2315-2324.

Zamani NP, Wardiatno Y, Nggajo R. 2011. Development strategy of yellowtail fusilier fish (Caesiocuning) resources management on coral ecosystem in The Seribu Islands. Saintek Perikanan: Indonesian J Fish Sci Technol 6: 37-52. 